\title{
Serum estradiol levels in controlled ovarian stimulation directly affect the endometrium
}

\author{
Kamran Ullah1,2,*, Tanzil Ur Rahman1,2,*, Hai-Tao Pan1,3, Meng-Xi Guo1,2, \\ Xin-Yan Dong1,2, Juan Liu1, Lu-Yang Jin1,2, Yi Cheng',2, Zhang-Hong Ke1, Jun Ren1,2, \\ Xian-Hua Lin ${ }^{4}$, Xiao-Xiao Qiư ${ }^{5}$, Ting-Ting Wang', He-Feng Huang ${ }^{1,4}$ and \\ Jian-Zhong Sheng1,2
}

1The Key Laboratory of Reproductive Genetics (Zhejiang University), Ministry of Education, Hangzhou, Zhejiang, China

2Department of Pathology and Pathophysiology, School of Medicine, Zhejiang University, Hangzhou, Zhejiang, China

3Shaoxing Women and Children's Hospital, Shaoxing, Zhejiang, China

${ }^{4}$ The International Peace Maternity and Child Health Hospital, School of Medicine, Shanghai Jiao Tong University, Shanghai, China

${ }^{5}$ Department of Pathophysiology, Wenzhou Medical University, Wenzhou, Zhejiang, China

*(K Ullah and T U Rahman contributed equally to this work)

Correspondence should be addressed to J-Z Sheng or H-F Huang Email

shengjz@zju.edu.cn or huanghefg@hotmail.com

\begin{abstract}
Previous studies have shown that increasing estradiol concentrations had a toxic effect on the embryo and were deleterious to embryo adhesion. In this study, we evaluated the physiological impact of estradiol concentrations on endometrial cells to reveal that serum estradiol levels probably targeted the endometrium in controlled ovarian hyperstimulation $(\mathrm{COH})$ protocols. An attachment model of human choriocarcinoma (JAr) cell spheroids to receptive-phase endometrial epithelial cells and Ishikawa cells treated with different estradiol (10-9 $\mathrm{M}$ or $\left.10^{-7} \mathrm{M}\right)$ concentrations was developed. Differentially expressed protein profiling of the Ishikawa cells was performed by proteomic analysis. Estradiol at 10-7 $\mathrm{M}$ demonstrated a high attachment rate of JAr spheroids to the endometrial cell monolayers. Using iTRAQ coupled with LC-MS/MS, we identified 45 differentially expressed proteins containing 43 significantly upregulated and 2 downregulated proteins in Ishikawa cells treated with $10^{-7} \mathrm{M}$ estradiol.

Differential expression of $C_{3}$, plasminogen and kininogen-1 by Western blot confirmed the proteomic results. $C_{3}$, plasminogen and kininogen-1 localization in human receptive endometrial luminal epithelium highlighted the key proteins as possible targets for endometrial receptivity and interception. Ingenuity pathway analysis of differentially expressed proteins exhibited a variety of signaling pathways, including LXR/RXR activation pathway and acute-phase response signaling and upstream regulators (TNF, IL6, Hmgn3 and miR-140-3p) associated with endometrial receptivity. The observed estrogenic effect on differential proteome dynamics in Ishikawa cells indicates that the human endometrium is the probable target for serum estradiol levels in $\mathrm{COH}$ cycles. The findings are also important for future functional studies with the identified proteins that may influence embryo implantation.
\end{abstract}

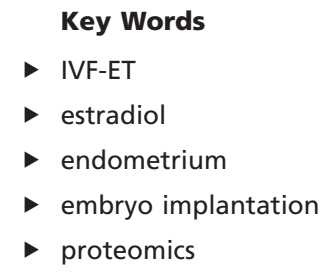

Journal of Molecular Endocrinology (2017) 59, 105-119 http://jme.endocrinology-journals.org DOI: 10.1530/JME-17-0036
(C) 2017 The authors Published by Bioscientifica Ltd. Printed in Great Britain

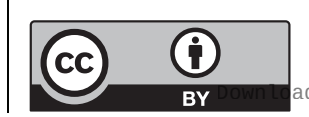

This work is licensed under a Creative Commons Attribution 3.0 Unported License. 


\section{Introduction}

Controlled ovarian hyperstimulation $(\mathrm{COH})$ is usually examined by serum estradiol $\left(\mathrm{E}_{2}\right)$ levels for IVF cycles. Serum estradiol $\left(\mathrm{E}_{2}\right)$, up to a certain level, influences embryonic implantation during $\mathrm{COH}$ in a concentrationdependent manner (Joo et al. 2010). Multiple ovarian follicle maturation will produce supraphysiological serum $E_{2}$ levels that may induce morphologic (Kolb et al. 1997) and biochemical (Simón et al. 1996) endometrial alterations related to uterine receptivity. In humans (Paulson et al. 1990, Ng et al. 2000) and mice (Fossum et al. 1989), COH led to an increase in estrogen to supraphysiological levels that might compromise embryo implantation, although this contrasts with other reports where elevated $\mathrm{E}_{2}$ levels were found to be associated with no change or increased implantation rate (Chenette $e t$ al. 1990, Sharara \& McClamrock 1999). Mirkin et al. (2004) reported that high $\mathrm{E}_{2}$ levels might impair endometrial receptivity, particularly when $\mathrm{COH}$ was used in conjunction with fresh embryo transfers. Clinical studies demonstrated different results. In high responders, regardless of the serum progesterone $\left(\mathrm{P}_{4}\right)$ levels, high serum $\mathrm{E}_{2}$ levels on the day of hCG administration were detrimental to uterine receptivity without affecting the embryo quality (Simón et al. 1998), while, decreasing $\mathrm{E}_{2}$ levels during the preimplantation period by a step-down protocol increased embryo implantation and pregnancy rates (Valbuena et al. 1999). On the other hand, one study found high pregnancy rates in higher responder patients (Papageorgiou et al. 2002). In vitro studies showed that increasing estradiol concentrations from $10^{-8} \mathrm{M}$ to $10^{-4} \mathrm{M}$ are deleterious to embryo adhesion because they directly affected the embryo (Valbuena et al. 2001). Recently, a novel mechanism of supraphysiological level of $\mathrm{E}_{2}$-induced Aqp5/8-dependent excessive intrauterine fluid accumulation predicted human implantation failure (Zhang et al. 2015). Proteomic analysis of the human receptive vs non-receptive endometrium showed differential proteomic repertoire during the window of implantation (Dominguez et al. 2009). However, the impact of high $\mathrm{E}_{2}$ levels to predict IVF outcome has been the subject of debate.

Following the reported research that serum $\mathrm{E}_{2}$ levels impact the pregnancy outcome of in vitro fertilization in a concentration-dependent manner, we undertook a more robust and accurate method of protein expression, quantification by mass spectrometry using iTRAQ isobaric tags coupled with 2D nano LC-MS/MS, to screen the comparative proteomic profiling of Ishikawa cells pretreated with different $\mathrm{E}_{2}\left(10^{-9} \mathrm{M}\right.$ or $\left.10^{-7} \mathrm{M}\right)$ concentrations. The Ishikawa cells have the characteristics of glandular and luminal epithelium along with structural proteins and apical adhesiveness to JAr cells and may serve as an excellent model for in vitro study of endocrine signaling in the endometrium (Castelbaum et al. 1997, Heneweer et al. 2005, Mo et al. 2006). The Ishikawa cell line also expresses MUC1 markers and steroid (estrogen, progesterone and androgen) receptors and is considered most useful for examining the early events and functional interactions that occur between the luminal epithelium and the trophectoderm (Hannan et al. 2010). The expression of proteins was also validated by Western blot. Protein localization in the endometrial luminal epithelium during the receptive phase $(\mathrm{LH}+7)$ was performed by immunofluorescence. The endometrium is receptive to embryonic implantation for a 2-day period (from $\mathrm{LH}+7$ to $\mathrm{LH}+9$ ) corresponding to days $21-23$ of the menstrual cycle, in the mid-secretory phase, the so-called 'window of implantation' (Dominguez et al. 2009).

The proteomic results, combined with immunofluorescent localization, will not only examine the physiological interactions of $\mathrm{E}_{2}$ with endometrium in $\mathrm{COH}$ cycles that is useful for in vitro fertilization (IVF), but should gain new insight into this complex processes as well. Identification of novel biomarkers affected with $\mathrm{E}_{2}$ concentrations represents a relatively unexplored area related to embryo implantation. Ingenuity pathway analysis (IPA) was used to determine affected pathways and predicted upstream regulators for the cells as well.

\section{Materials and methods}

\section{Patients and sample collection}

Ethical approval for this study was granted by the Ethics Committee of School of Medicine, Zhejiang University. A written informed consent was obtained from each subject before tissue collection. These women were healthy and not taking any drugs in the past six months. They attended Women's Hospital, School of Medicine, Zhejiang University to undergo in vitro fertilization and embryo transfer (IVF-ET) treatment because of infertility due to tubule pathology without hydrosalpinges. The receptivephase $(\mathrm{LH}+7)$ endometrial samples were obtained with a biopsy catheter during the spontaneous menstrual cycle for diagnostic purposes before IVF-ET cycle. Shortly after collection, some endometrial tissues were fixed in

Published by Bioscientifica Ltd. 
$10 \%$ formalin and processed for paraffin embedding, and others were placed into the DMEM/F-12 medium (HyClone, Logan, UT, USA) for cell culture within $2 \mathrm{~h}$.

\section{Cells and cell culture}

Endometrial tissues were cut into $2-3 \mathrm{~mm}$ pieces and digested with $1 \mathrm{mg} / \mathrm{mL}$ of collagenase type $1 \mathrm{~A}$ in DMEM/ F12 for $1.5 \mathrm{~h}$ at $37^{\circ} \mathrm{C}$. It was then filtered through $250 \mu \mathrm{m}$ nylon sieve to remove mucus and undigested tissue. The filter was passed through a $40 \mu \mathrm{m}$ nylon sieve, which allowed the stromal cells to pass through, while intact glands were retained. Glands were recovered from the filter by backwashing with DMEM/F12 containing 10\% bovine serum albumin and seeded on to the six-well plates for future study for certain durations.

The Ishikawa cell line (American Type Culture Collection, Manassas, VA, USA) was obtained from Shanghai Institutes for Biological Science and maintained in RPMI-1640 medium (Gibco; Thermo Fisher Scientific) containing $10 \%$ fetal bovine serum (FBS) and $100 \mathrm{U} / \mathrm{mL}$ penicillin and streptomycin antibiotics. When the cells reached confluence, the medium was replaced with phenol red free RPMI-1640 supplemented with 10\% charcoal/dextran-treated FBS (all purchased from SigmaAldrich). For hormonal treatments, $\mathrm{E}_{2}$ (Sigma-Aldrich) was added to the culture media to a final concentration of $10^{-9} \mathrm{M}$ (close to the physiological concentration in women at the mid-secretory phase) and $10^{-7} \mathrm{M}$ (close to the supraphysiological concentration in women with controlled ovarian hyperstimulation), for certain durations according to the experimental purposes (Valbuena et al. 2001).

\section{JAr spheroid attachment to endometrial epithelial cell monolayers}

In in vitro attachment model, multicellular spheroids of human choriocarcinoma (JAr) cells (American Type Culture Collection, Manassas, VA, USA; HTB 144) were applied to receptive-phase human endometrial epithelial cell monolayers and Ishikawa cell layers, respectively. The endometrial epithelial cells were pretreated with $10^{-9} \mathrm{M}$ or $10^{-7} \mathrm{M} \mathrm{E}_{2}$ and cultured for 3 days. JAr spheroids were prepared according to a standard procedure (Hohn et al. 2000) and transferred onto the surface of confluent cell monolayers for $1 \mathrm{~h}$ (50 spheroids/dish for primary cultured endometrial cells and 45 spheroids/dish for Ishikawa cells). Non-adherent spheroids were detached by centrifugation $(10 \boldsymbol{g} ; 10 \mathrm{~min})$ of the six-well plates with the cell surface facing down. We counted the attached spheroids under a light microscope and the attachment rate was calculated for each well as follows: attachment rate equals the ratio of the number of spheroids attached to the number of spheroids seeded. This experiment was repeated at least three times.

\section{Protein extraction}

Protein extractions from Ishikawa cells treated with $10^{-9} \mathrm{M}$ and $10^{-7} \mathrm{M} \mathrm{E}_{2}$, respectively, were performed with cell lysis buffer ( $4 \%$ SDS, $1 \mathrm{mM}$ DTT, $150 \mathrm{mM}$ Tris-HCl, $\mathrm{pH} 8.0$ ) at $95^{\circ} \mathrm{C}$ for $20 \mathrm{~min}$, followed by sonication on ice. The crude extracts were incubated at $95^{\circ} \mathrm{C}$ for $5 \mathrm{~min}$ and cleared by centrifugation (SCILOGEX D3024R, Inc., Rocky Hill, CT, USA) at $14,000 \boldsymbol{g}$ for $30 \mathrm{~min}$ at $15^{\circ} \mathrm{C}$. Thereafter, the supernatant was collected and protein concentration was measured by the BCA protein assay reagent (Pierce).

\section{Protein digestion and iTRAQ labeling}

Protein digestion was performed according to the FASP procedure (Wisniewski et al. 2009). Four biological replicates were included in the analysis. Briefly, $200 \mu \mathrm{g}$ of total protein samples were diluted in $30 \mu \mathrm{L} 4 \%$ SDS, $100 \mathrm{mM}$ Tris- $\mathrm{HCl} \mathrm{pH} 8.0$ and $100 \mathrm{mM}$ dithiothreitol solution and heated at $95^{\circ} \mathrm{C}$ for $5 \mathrm{~min}$. After each sample was cooled to room temperature, it was loaded onto an ultrafiltration filter (cutoff $10 \mathrm{kDa}$, Sartorius, Germany). We added $200 \mu \mathrm{L}$ UT buffer ( $8 \mathrm{M}$ Urea and $150 \mathrm{mM}$ Tris$\mathrm{HCl}, \mathrm{pH} 8.0)$ to the filter and centrifuged it at $14,000 \mathrm{~g}$ at $20^{\circ} \mathrm{C}$ for $30 \mathrm{~min}$. Subsequently, $100 \mu \mathrm{L}$ of iodoacetamide solution (50 mM iodoacetamide in UT buffer) was added for blocking reduced cysteines, and the samples were further incubated for $20 \mathrm{~min}$ in darkness. The filters were centrifuged at $14,000 \mathrm{~g}$ at $20^{\circ} \mathrm{C}$ for $20 \mathrm{~min}$ and washed (twice) with $100 \mu \mathrm{L}$ UT buffer at $14,000 \boldsymbol{g}$ for further $20 \mathrm{~min}$. The dissolution buffer $(100 \mu \mathrm{L}, \mathrm{AB}$ Sciex, Framingham, MA, USA) was added to the filter followed by centrifugation at $14,000 \mathrm{~g}$ at $20^{\circ} \mathrm{C}$ for $30 \mathrm{~min}$. This step was repeated twice. Finally, $40 \mu \mathrm{L}$ of trypsin (Promega) buffer ( $2 \mu \mathrm{g}$ trypsin in $40 \mu \mathrm{L}$ dissolution buffer) was added, and the samples were digested overnight at $37^{\circ} \mathrm{C}$. Each filter unit was transferred to a new tube and centrifuged at $14,000 \mathrm{~g}$ at $20^{\circ} \mathrm{C}$ for $30 \mathrm{~min}$. The resulting peptide concentrations were estimated by UV light spectral density at OD280 (Sheng et al. 2012). Then, the peptide mixtures were labeled using the 8-plex iTRAQ reagent http://jme.endocrinology-journals.org DOI: 10.1530/JME-17-0036
() 2017 The authors Printed in Great Britain
Published by Bioscientifica Ltd 
according to the manufacturer's instructions (AB Sciex, Framingham). Four samples from control group, treated with $10^{-9} \mathrm{M} \mathrm{E}_{2}$, were labeled with mass $114,115,116$ and 117 isobaric iTRAQ tags, while the other four samples from high $\mathrm{E}_{2}$ group $\left(10^{-7} \mathrm{M} \mathrm{E}_{2}\right)$ were labeled with mass $118,119,120$ and 121 isobaric iTRAQ tags. The labeling solution was incubated at room temperature for $2 \mathrm{~h}$ before further analysis.

\section{Strong cationic exchange chromatography separation}

The combined sample was acidified $(\mathrm{pH}=8.0)$ with $1 \%$ trifluoroacetic acid before being subjected to strong cationic-exchange chromatography (SCX) fractionation using a PolySULFOETHYL column $(4.6 \times 100 \mathrm{~mm}, 5 \mu \mathrm{m}$, $200 \AA$, Poly LC Inc., Columbia, MD, USA). Solvent A

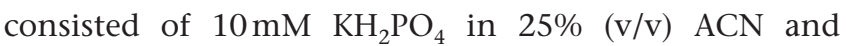
solvent $\mathrm{B}$ was solvent $\mathrm{A}$ with $500 \mathrm{mM} \mathrm{KCl}$ added. The solvents were applied using a gradient of $0-10 \%$ solvent B for $2 \mathrm{~min}, 10-20 \%$ solvent B for $25 \mathrm{~min}, 20-45 \%$ solvent B for $5 \mathrm{~min}$ and $50-100 \%$ solvent B for $5 \mathrm{~min}$. The elution was monitored by absorbance at $214 \mathrm{~nm}$ and fractions were collected every $1 \mathrm{~min}$. Finally, these samples were combined into 10 fractions based on the quantity of peptide and then desalted on C18 cartridges (Sigma). Each SCX salt step fraction was dried in a vacuum centrifuge and reconstituted with $40 \mu \mathrm{L} 0.1 \%$ (v/v) trifluoroacetic acid.

\section{LC-ESI-MS/MS analysis}

Peptide mixture $(5 \mu \mathrm{g})$ from each fraction was subjected to nano LC-MS/MS analysis. The mixtures were loaded onto the Thermo EASY-nLC column (Thermo Finnigan, San Jose, CA, USA) $(100 \mathrm{~mm} \times 75 \mu \mathrm{m}, 3 \mu \mathrm{m})$ in solvent C $(0.1 \%$ formic acid) and separated with a linear gradient of solvent D (80\% acetonitrile with $0.1 \%(\mathrm{v} / \mathrm{v})$ formic acid) at a flow rate of $300 \mathrm{~nL} / \mathrm{min}$ over $120 \mathrm{~min}$ : $0-100 \mathrm{~min}$ with 0-45\% solvent D; $100-108$ min with $45-100 \%$ solvent D and $108-120 \mathrm{~min}$ with $100 \%$ solvent D. The Q-Exactive (Thermo Finnigan) mass spectrometer acquired data in the positive ion mode $(2.2 \mathrm{kV})$ with a selected mass range of 300-800 mass/charge (m/z). Dynamic exclusion was used with 40.0 s duration. Q-Exactive survey scans were set as 70,000 at $\mathrm{m} / \mathrm{z} 200$ and 17,500 at m/z 200 of resolution for HCD spectra. MS/MS data were acquired using a datadependent acquisition method with the top 10 most abundant precursor ions. The normalized collision energy was $30 \mathrm{eV}$ and the under fill ratio was defined as $0.1 \%$ on the Q-Exactive.

\section{Protein identification and quantification}

Protein identification and quantification were performed with high accuracy using MaxQuant, version 1.2.2.5 software in combination with Andromeda search engine (Cox et al. 2011). The acquired data from triplicate MS runs for each sample were combined and searched against an International Protein Index (IPI 3.83) human protein sequence database using the MaxQuant computational proteomics platform, version 1.2.0.18 (Cox \& Mann 2008). A decoy version of the IPI human database was used to estimate peptide and protein false discovery rate. A FDR of 0.01 was applied for both protein and peptide identification, ensuring that at most only $1 \%$ of proteins would be falsely identified. Ratios were obtained for both the groups $10^{-9} \mathrm{M}$ to $10^{-7} \mathrm{M} \mathrm{E}_{2}$ and then inversed. Significant protein ratio, cutoff, was set at a significance $B$ value $\leq 0.05$ as calculated by MaxQuant (Cox \& Mann 2008, Cox et al. 2009). Carbamidomethylation of cysteine was set as a fixed modification, with protein $\mathrm{N}$-terminal acetylation and oxidation of methionine as variable modifications, enzyme: trypsin/P, maximum number of missed cleavages. The processed MS data generated by MaxQuant are presented in the supporting information data Table 1.

\section{Western blotting analysis}

The cell extracts were prepared by lysing unsorted epithelial cells with RIPA buffer containing $150 \mathrm{mM} \mathrm{NaCl}, 50 \mathrm{mM}$ Tris- $\mathrm{HCl}(\mathrm{pH}=8), 1 \% \mathrm{NP}-40,0.5 \%$ sodium deoxycholate, $0.1 \%$ SDS, protease inhibitors and phosphatase inhibitors (Sigma). The cell extract $(20 \mu \mathrm{g})$ was run on an $8-10 \%$ SDS-PAGE gel and transferred to a nitrocellulose transfer membrane (Bio-Rad). After incubating for $1 \mathrm{~h}$ with blocking buffer, the membrane was incubated overnight at $4^{\circ} \mathrm{C}$ with mouse monoclonal anti-complement $\mathrm{C}_{3}$ (1:500 Santa Cruz Biotechnology sc28294), mouse monoclonal anti-plasminogen (1:500 Santa Cruz Biotechnology sc376324), rabbit polyclonal anti-kininogen 1 (1:1000 Abcam ab97761) and mouse polyclonal anti-GAPDH antibody (1:5000 Novus Biologicals, Littleton, CO, USA). After three washes with $1 \times$ TBST, pH 7.4, the samples were then incubated with fluorescence-labeled anti-mouse IgG or anti-rabbit IgG antibody (Daylight 680 or 800, KPL; http://jme.endocrinology-journals.org DOI: 10.1530/JME-17-0036
(C) 2017 The authors Printed in Great Britain
Published by Bioscientifica Ltd 


\begin{tabular}{|c|c|c|c|c|c|c|c|c|}
\hline$P$ value & $\begin{array}{l}\text { Fold } \\
\text { change }\end{array}$ & $\begin{array}{l}\text { Accession } \\
\text { code }\end{array}$ & Protein description & Score & $\begin{array}{c}\text { Cover-age } \\
(\%)\end{array}$ & $\begin{array}{c}\text { Mol. Wt } \\
(\mathrm{kDa})\end{array}$ & $\begin{array}{c}\text { Unique } \\
\text { peptides }\end{array}$ & Gene symbol \\
\hline $1.69 \mathrm{E}-02$ & -1.47 & E5RK39 & $\begin{array}{l}\text { Ribonucleases P/MRP protein subunit } \\
\text { POP1 }\end{array}$ & 2.8711 & 10.4 & 20.7 & 2 & POP1 \\
\hline $3.27 \mathrm{E}-02$ & -1.34 & Q9Y6K0 & $\begin{array}{l}\text { Choline/ } \\
\text { ethanolaminephosphotransferase } 1\end{array}$ & 3.1822 & 4.8 & 46.553 & 2 & CEPT1 \\
\hline $3.59 \mathrm{E}-02$ & 1.3 & Q9NZ08 & $\begin{array}{l}\text { Endoplasmic reticulum } \\
\text { aminopeptidase } 1\end{array}$ & 12.72 & 5.2 & 107.23 & 3 & ERAP1 \\
\hline $2.83 \mathrm{E}-02$ & 1.3 & P10412 & Histone H1.4 & 17.536 & 48.4 & 21.865 & 4 & HIST1H1E \\
\hline 4.18E-02 & 1.31 & P01044 & Kininogen-1 & 26.763 & 9.7 & 68.964 & 5 & KNG1 \\
\hline 2.37E-03 & 1.31 & Q9C0J8 & $\begin{array}{l}\text { Pre-mRNA } 3^{\prime} \text { end processing protein } \\
\text { WDR33 }\end{array}$ & 5.6023 & 2.7 & 145.89 & 2 & WDR33 \\
\hline 4.03E-02 & 1.31 & P06868 & Plasminogen & 17.058 & 6.4 & 91.215 & 5 & PLG \\
\hline $1.66 \mathrm{E}-02$ & 1.31 & I3LON3 & Vesicle-fusing ATPase & 70.446 & 24.1 & 82.091 & 16 & NSF \\
\hline 4.74E-03 & 1.31 & Q9UH99 & SUN domain-containing protein 2 & 85.535 & 16.1 & 79.085 & 7 & SUN2 \\
\hline $1.31 \mathrm{E}-02$ & 1.32 & Q28085 & Complement factor $\mathrm{H}$ & 4.3809 & 1.2 & 140.37 & 2 & $\mathrm{CFH}$ \\
\hline 4.35E-04 & 1.32 & Q3MHN2 & Complement component C9 & 139.78 & 16.2 & 61.998 & 6 & $\mathrm{C} 9$ \\
\hline $4.80 \mathrm{E}-02$ & 1.33 & Q71DI3 & Histone H3.2 & 14.879 & 28.7 & 15.388 & 1 & $\mathrm{HIST} 2 \mathrm{H} 3 \mathrm{~A}$ \\
\hline $2.63 \mathrm{E}-03$ & 1.34 & Q0VCM5 & $\begin{array}{l}\text { Inter-alpha-trypsin inhibitor heavy } \\
\text { chain } \mathrm{H} 1\end{array}$ & 52.463 & 5.4 & 101.24 & 3 & ITIH1 \\
\hline $1.13 \mathrm{E}-02$ & 1.35 & Q3KUS7 & Complement factor B & 24.379 & 5.9 & 85.411 & 4 & BF \\
\hline $1.45 \mathrm{E}-02$ & 1.35 & P02070 & Hemoglobin subunit beta & 137.67 & 68.3 & 15.954 & 9 & HBB \\
\hline 4.00E-02 & 1.35 & P01966 & Hemoglobin subunit alpha & 87.333 & 66.9 & 15.184 & 8 & HBA \\
\hline $3.11 \mathrm{E}-02$ & 1.37 & J3KMX2 & $\begin{array}{l}\text { SWI/SNF-related matrix-associated } \\
\text { actin-dependent regulator of } \\
\text { chromatin subfamily D member } 2\end{array}$ & 4.5084 & 8.3 & 52.238 & 2 & SMARCD2 \\
\hline $1.71 \mathrm{E}-02$ & 1.37 & E9PH82 & Protein FAM98A & 50.655 & 20.8 & 34.431 & 4 & FAM98A \\
\hline $3.34 \mathrm{E}-02$ & 1.39 & Q9UDR5 & $\begin{array}{l}\text { Alpha-aminoadipic semialdehyde } \\
\text { synthase, mitochondrial }\end{array}$ & 5.4278 & 3.9 & 102.13 & 3 & AASS \\
\hline 8.02E-03 & 1.4 & E9PJ95 & COMM domain-containing protein 9 & 12.306 & 11.4 & 20.687 & 1 & COMMD9 \\
\hline 3.77E-03 & 1.51 & Q3SZV7 & Hemopexin & 19.7 & 11.1 & 52.295 & 5 & $\mathrm{HPX}$ \\
\hline $1.03 \mathrm{E}-02$ & 1.52 & P50448 & Factor XIla inhibitor & 37.23 & 8.8 & 51.723 & 3 & N/A \\
\hline $6.31 \mathrm{E}-05$ & 1.52 & P21752 & Thymosin beta-10 & 38.232 & 33.3 & 4.8054 & 2 & TMSB 10 \\
\hline $3.91 \mathrm{E}-04$ & 1.53 & Q3MHN5 & Vitamin D-binding protein & 16.019 & 9.1 & 53.341 & 4 & $\mathrm{GC}$ \\
\hline $2.78 \mathrm{E}-03$ & 1.54 & Q05B55 & IGK protein & 5.2815 & 7.9 & 26.59 & 2 & IGK \\
\hline 2.63E-04 & 1.55 & A217N3 & Serpin A3-7 & 4.3669 & 10.1 & 46.941 & 2 & SERPINA3-7 \\
\hline 8.23E-04 & 1.59 & Q2UVX4 & Complement C3 & 323.31 & 33.9 & 187.37 & 48 & $\mathrm{C} 3$ \\
\hline 3.06E-03 & 1.6 & Q9UBI6 & $\begin{array}{l}\text { Guanine nucleotide-binding protein } \\
\mathrm{G}(\mathrm{I}) / \mathrm{G}(\mathrm{S}) / \mathrm{G}(\mathrm{O}) \text { subunit gamma-12 }\end{array}$ & 12.514 & 47.2 & 8.0061 & 3 & GNG12 \\
\hline $1.52 \mathrm{E}-03$ & 1.62 & BOYIW2 & Apolipoprotein C-III & 94.585 & 13.7 & 12.815 & 1 & APOC3 \\
\hline 2.07E-03 & 1.63 & B9A064 & $\begin{array}{l}\text { Immunoglobulin lambda-like } \\
\text { polypeptide } 5\end{array}$ & 2.1299 & 3.7 & 23.063 & 1 & IGLL5 \\
\hline $3.80 \mathrm{E}-04$ & 1.65 & Q3T052 & $\begin{array}{l}\text { Inter-alpha-trypsin inhibitor heavy } \\
\text { chain } \mathrm{H} 4\end{array}$ & 29.331 & 9.6 & 101.51 & 9 & ITIH4 \\
\hline $5.03 \mathrm{E}-04$ & 1.68 & P12763 & $\begin{array}{l}\text { Alpha-2-Heremans Schmidt (HS) } \\
\text { glycoprotein }\end{array}$ & 21.332 & 14.2 & 38.418 & 5 & AHSG \\
\hline $1.96 \mathrm{E}-03$ & 1.71 & P17697 & Clusterin & 2.0487 & 2.3 & 51.113 & 1 & CLU \\
\hline $1.29 \mathrm{E}-03$ & 1.78 & Q9TRI1 & $\begin{array}{l}\text { Inter-alpha-trypsin inhibitor HC2 } \\
\text { component homolog }\end{array}$ & 35.657 & 4.7 & 106.19 & 3 & N/A \\
\hline $1.09 \mathrm{E}-04$ & 1.92 & Q9TTE1 & Serpin A3-1 & 132.16 & 21.7 & 46.203 & 3 & SERPINA3-1 \\
\hline $1.34 \mathrm{E}-04$ & 1.97 & P15497 & Apolipoprotein A-I & 185.73 & 61.1 & 30.276 & 16 & APOA1 \\
\hline $3.22 \mathrm{E}-04$ & 2.02 & Q2KIT0 & Protein HP-20 homolog & 9.9797 & 13.1 & 20.646 & 2 & N/A \\
\hline $2.50 \mathrm{E}-04$ & 2.06 & A2I7N0 & Serpin A3-5 & 39.18 & 17.8 & 46.397 & 2 & SERPINA3-5 \\
\hline 1.05E-04 & 2.09 & Q29443 & Serotransferrin & 138.25 & 28.7 & 77.738 & 16 & $\mathrm{TF}$ \\
\hline $1.54 \mathrm{E}-04$ & 2.09 & P81644 & Apolipoprotein A-II & 14.097 & 35 & 11.202 & 3 & APOA2 \\
\hline $1.65 \mathrm{E}-04$ & 2.1 & Q3SZR3 & Alpha-1-acid glycoprotein & 60.603 & 30.7 & 23.182 & 6 & ORM1 \\
\hline $1.83 \mathrm{E}-04$ & 2.19 & Q1RMN8 & $\begin{array}{l}\text { Immunoglobulin light chain, lambda } \\
\text { gene cluster }\end{array}$ & 27.788 & 17.9 & 24.536 & 3 & IGL@ \\
\hline $6.33 \mathrm{E}-05$ & 2.3 & P02769 & Serum albumin & 323.31 & 30.6 & 69.293 & 21 & ALB \\
\hline $1.26 \mathrm{E}-03$ & 2.47 & P43366 & Melanoma-associated antigen B1 & 1.785 & 2.6 & 39.037 & 1 & MAGEB1 \\
\hline 2.79E-04 & 2.84 & Q2KJF1 & Alpha-1B-glycoprotein & 43.931 & 11.7 & 53.553 & 4 & A1BG \\
\hline
\end{tabular}

http://jme.endocrinology-journals.org DOI: 10.1530/JME-17-0036
() 2017 The authors Printed in Great Britain
Published by Bioscientifica Ltd. 
1:5000) for $1 \mathrm{~h}$ at room temperature and analyzed with an Odyssey Imager (Li-Cor; Lincoln, NE, USA).

\section{Immunofluorescence analysis}

Human endometrial samples at the receptive phase $(\mathrm{LH}+7)$ were used for immunofluorescence validation. Samples were fixed in 10\% formalin and processed for paraffin embedding. Cross-sections (5 $\mu \mathrm{m}$ thickness) were mounted onto microscope slides (Thermo Fisher Scientific). After deparaffinization and rehydration, sections were rinsed three times with phosphate buffered saline (PBS) for $5 \mathrm{~min}$. Immunofluorescence analysis was performed on endometrial sections using the LSAB Peroxidase Kit (DAKO). Non-specific binding was blocked with $5 \%$ bovine serum albumin (BSA). Sections were incubated with the following primary antibodies diluted (1:100) in blocking solution $(0.25 \%$ BSA, $0.3 \%$ Triton $\mathrm{X}-100$, sterile PBS) overnight at $4^{\circ} \mathrm{C}$. Plasminogen (Abcam 154560), Kininogen 1 (Abcam ab97761), ER $\alpha$ (Abcam ab108398) and $\mathrm{C}_{3}$ (Proteintech, 21337-1-AP, Chicago, IL, USA). Tissue sections were then washed with PBS for $5 \mathrm{~min}$. For the fluorescent detection (anti-plasminogen, anti-kininogen 1, anti- $\mathrm{C}_{3}$ and anti-ER $\alpha$ ), Alexa Fluor 488 goat anti-rabbit (dilution 1:100, Thermo Fisher Scientific) secondary antibody was used and nuclear counterstaining was performed with 4,6-diamidino-2-phenylindole (DAPI, Molecular Probes/Life Technologies). Evaluation of the sections was performed using confocal laser scanning microscopy (Zeiss 800, LSM 510 Meta).

\section{Bioinformatics analysis}

Differentially expressed protein profiles $(P<0.05)$ were selected and the ones with differential expression ratio of over \pm 1.2 were retained. The capability of the resulting differentially expressed proteins in differentiating two groups of samples was then evaluated by hierarchical cluster analysis. For this purpose, the Cluster 3.0 (http:// bonsai.hgc.jp/ mdehoon/software/cluster/software. htm) and the Java Tree view software (http://jtreeview. sourceforge.net) were used. Disease analysis, pathway and network generation were performed using IPA software package (QIAGEN). IPA is a knowledge database relying on published literature related to protein function, localization, relevant interactions and biological mechanisms. Calculated the $z$-score can infer the activation states ('activated' or 'inhibited') of implicated biological processes.

\section{Statistical analysis}

GraphPad Prism 6 (GraphPad Software) was used for statistical analysis. Fisher's exact test was used to calculate a $P$ value to determine the probability that the association between proteins in the dataset, and, the biological process could be explained by chance alone. Using Student (unpaired) $t$-test, statistical significance for comparison between two groups was determined. Four biological replicates were tested for all samples and the data are expressed as means \pm s.D. $P<0.05$ was considered significant.

\section{Ethics approval and consent to participate}

The study was approved by the ethical committee of Zhejiang University, Hangzhou 310058, China. Written informed consent for study participation was obtained from the participants.

\section{Results}

Effects of $E_{2}$ at different concentrations on JAr spheroid attachment to human endometrial epithelial cell monolayers

To clarify whether treatments of human endometrium with different estrogen concentrations affected embryo implantation, we used in vitro attachment model of human choriocarcinoma JAr cell spheroids to receptive-phase endometrial epithelial cell monolayers and Ishikawa cell monolayers (Fig. 1A, B, C, D, E and F). The attachment rate of JAr spheroids to the endometrial cells pretreated with $10^{-9} \mathrm{M} \mathrm{E}_{2}$ for 3 days was $69.33 \pm 2.40 \%$. However, the attachment rate was enhanced to $80.67 \pm 1.76 \%$ after treatment of the epithelial cells with $10^{-7} \mathrm{M} \mathrm{E}_{2}$ (Fig. 1G). On the other hand, the attachment rate of JAr spheroids to the Ishikawa cells pretreated with $10^{-9} \mathrm{M} \mathrm{E}_{2}$ for 3 days was $65.1 \pm 2.08 \%$ and the attachment rate was also enhanced to $77.5 \pm 2.56 \%$ after treatment of the Ishikawa cells with $10^{-7} \mathrm{M} \mathrm{E}_{2}$ (Fig. $1 \mathrm{H}$ ). These results suggest that, compared to $10^{-9} \mathrm{M} \mathrm{E}_{2}, 10^{-7} \mathrm{M} \mathrm{E} \mathrm{E}_{2}$ may improve the endometrial receptivity.

\section{Protein expression profiles in cells treated with different concentrations of $E_{2}$}

The iTRAQ analysis was performed to identify proteome changes in samples of Ishikawa cells treated with different $\mathrm{E}_{2}$ concentrations $\left(10^{-9} \mathrm{M}\right.$ or $\left.10^{-7} \mathrm{M}\right)$. Protein identification

Published by Bioscientifica Ltd 

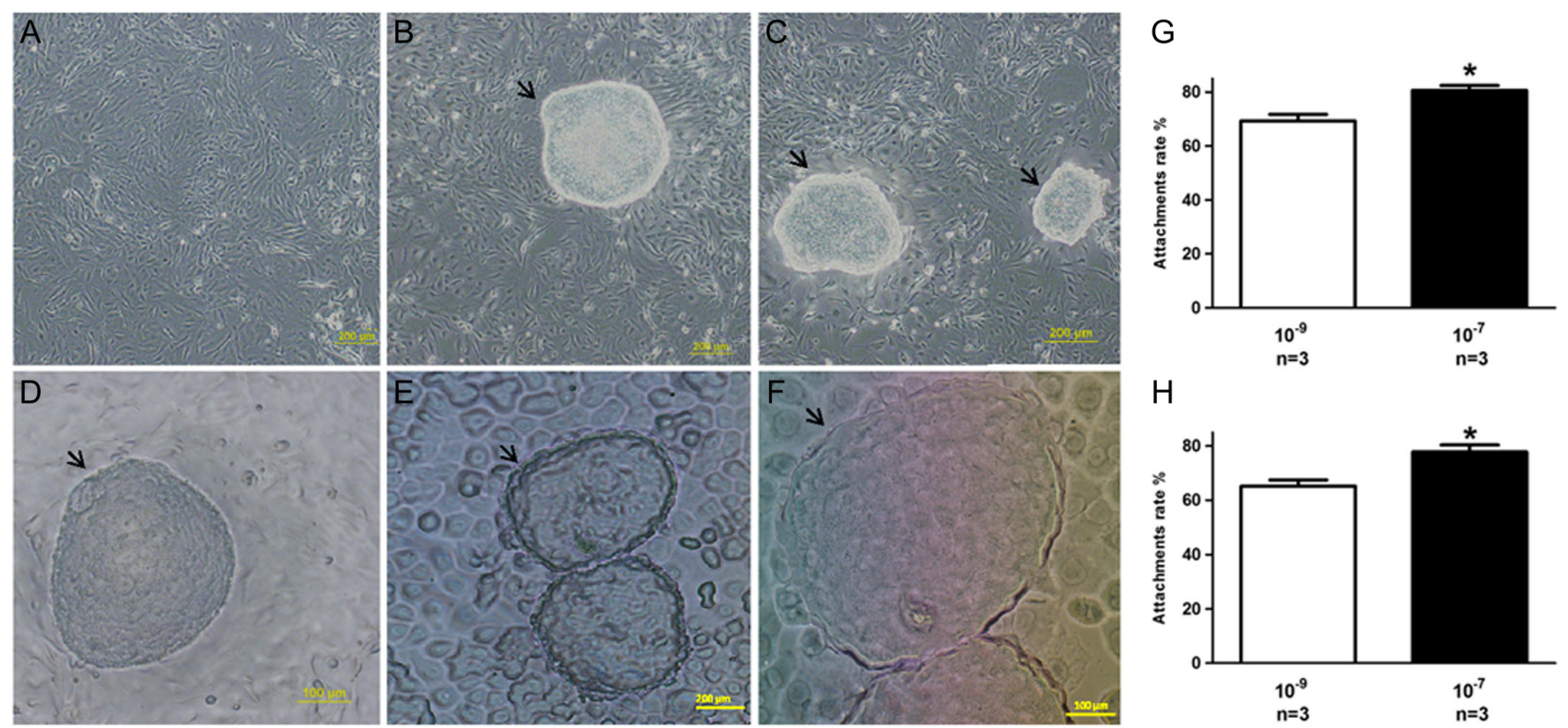

Figure 1

Effect of $E_{2}$ on JAr adhesion in treated human endometrial epithelial cells and Ishikawa cells. (A) Receptive-phase human endometrial epithelial cells treated with different $E_{2}$ concentrations. (B) and (C) Attachment of JAr spheroids to $10^{-9} \mathrm{M} \mathrm{E}_{2}$ - and 10-7 $\mathrm{M} \mathrm{E}_{2}$-treated cells, respectively (magnification 10X). (D) JAr spheroids attachment (magnification 20X). (E) and (F) JAr spheroids attachment to the Ishikawa cell monolayers (magnification 10X; 20X). Arrow indicates JAr spheroids. $(G)$ and $(H)$ Attachment rate of Jar spheroids to human endometrial epithelial cells and Ishikawa cells, respectively. Data are present as mean \pm S.D. $n=$ the times of experiment repeated. ${ }^{*} P<0.05$ compared with control. A full colour version of this figure is available at http://dx.doi.org/10.1530/JME-17-0036.

and quantification from the four biological replicates were subjected to LC-MS/MS and MaxQuant (MQ) (1.2.2.5) analysis. According to the UniProtKB Homo sapiens reference proteome database containing 70,136 canonical and isoform sequences through MaxQuant's built-in Andromeda search engine, a total of 2709 cellular proteins were considered to be statistically significant following exclusion, including 2362 upregulated proteins and 347 downregulated proteins (Fig. 2A). A FDR was applied combined with filtering out those ratios with a significance of $B$ value $\leq 0.05$. Compared with the control group $\left(10^{-9} \mathrm{ME}_{2}\right), 45$ differentially expressed proteins in Ishikawa cells treated with $10^{-7} \mathrm{M} \mathrm{E}_{2}$ were identified, containing 43 upregulated and 2 downregulated proteins (Table 1). The hierarchical clustering of these differentially expressed protein profiles are visualized in a heat map (Fig. 2B). Results showed a striking separation of the two groups into two major opposing branches, indicating that the proteins expressed in $10^{-7} \mathrm{M} \mathrm{E}_{2}$-treated group were distinct from those treated with $10^{-9} \mathrm{M} \mathrm{E}_{2}$.

\section{Validation of differentially expressed proteins by Western blot analysis}

To confirm the proteomic results, three upregulated proteins with known roles in embryo adhesion including complement $\left(\mathrm{C}_{3}\right)$, plasminogen and kininogen-1 were validated by Western blot analysis in both the groups. The results revealed that $C_{3}$, plasminogen and kininogen-1 were indeed highly expressed in Ishikawa cells treated with $10^{-7} \mathrm{M} \mathrm{E}_{2}$ (Fig. 3A, B and C). These results were essentially in agreement with those of proteomic analysis, suggesting that $1^{-7} \mathrm{M} \mathrm{E}_{2}$ might increase $\mathrm{C}_{3}$, plasminogen and kininogen-1 expression levels in endometrial cells, which in turn might promote the adhesion of JAr spheroids to the human endometrial cell monolayers.

\section{Localization of $\mathrm{C}_{3}, \mathrm{KNG} 1, \mathrm{PLG}$ and $\mathrm{ER} \alpha$ in the receptive endometrium}

As C3, KNG1, PLG and ER $\alpha$ (alpha) have been shown to have major roles in endometrial receptivity, we analyzed the location of these proteins in the human endometrium at the receptive phase by immunofluorescence. The staining (green) of C3 and PLG was shown in luminal epithelium (LE) and glandular epithelium (GE), largely restricted to apical surface of luminal and glandular epithelial cells. Furthermore, stromal cells (SC) also expressed higher density of C3 and PLG at the receptive phase. KNG1 and ERo followed the opposite trend, with a stronger intensity (green) in the LE and GE apical surfaces in the receptive endometrium (Fig. 4). http://jme.endocrinology-journals.org DOI: 10.1530/JME-17-0036
() 2017 The authors Printed in Great Britain
Published by Bioscientifica Ltd 
A

\begin{tabular}{|c|c|c|}
\hline & $\begin{array}{c}\text { Quantitative } \\
\text { Proteins }\end{array}$ & $\begin{array}{c}\text { Differentially } \\
\text { Expressed } \\
\text { Proteins }\end{array}$ \\
\hline Up-regulated & 2362 & 43 \\
\hline Down-regulated & 347 & 02 \\
\hline Total & 2709 & 45 \\
\hline
\end{tabular}

B

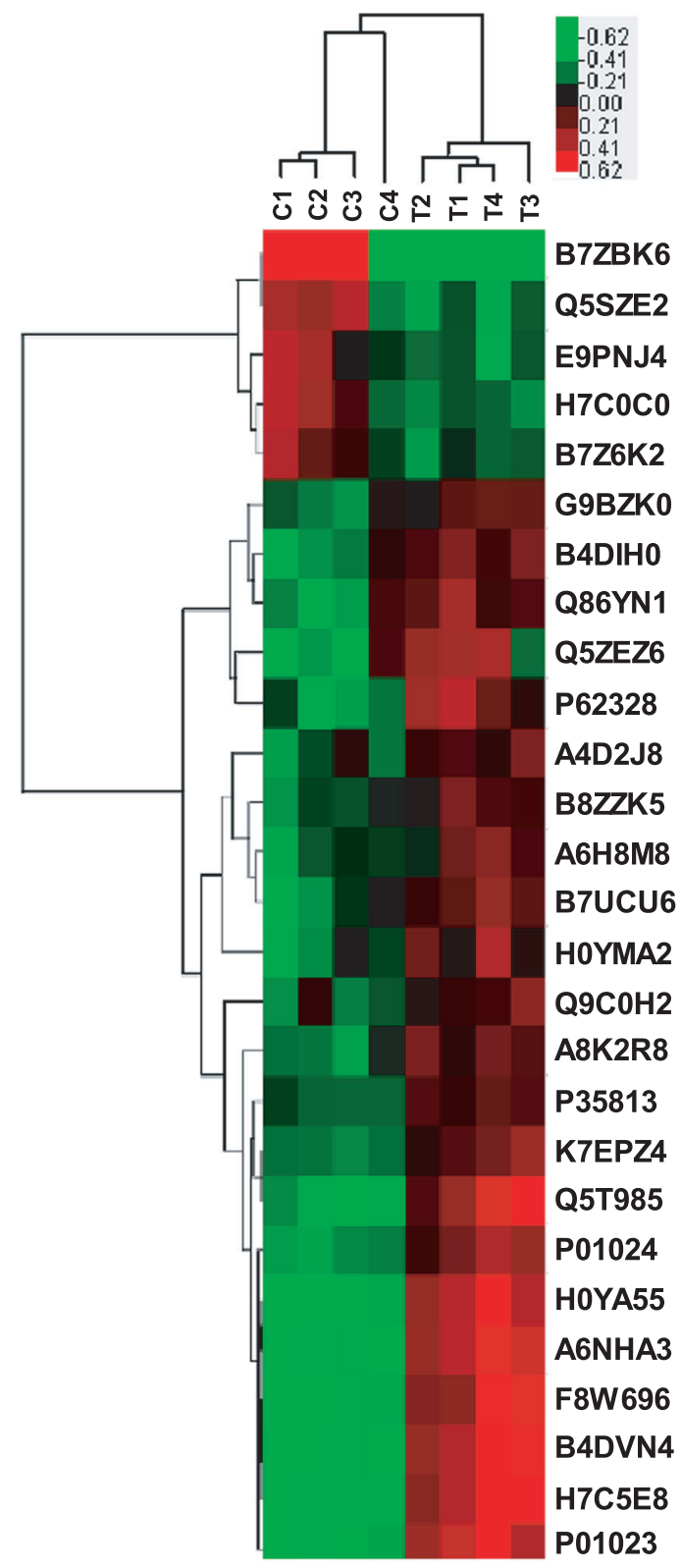

Figure 2

Altered protein profiles identified in Ishikawa cells. (A) The number of identified proteins including both upregulated and downregulated proteins. (B) Hierarchical clustering of differentially expressed protein profiles (red: upregulated proteins; green: downregulated proteins; black portrays: no change). Bar color represents a logarithmic scale from -0.62 to +0.62 .

\section{Ingenuity pathway analysis (IPA) yielded distinct functional groupings}

IPA was applied to analyze the relationship among 45 differentially expressed protein profiles based on their interaction and function. The results showed that most of the differentially expressed proteins in human endometrial epithelial cells treated with $\mathrm{E}_{2}\left(10^{-7} \mathrm{M}\right)$ were associated with organization of 'molecular and cellular functions' (Fig. 5A), 'physiological system and functions' (Fig. 5B) and 'disease and disorder' (Fig. 5C). Based on overlying $P$ values, differentially expressed proteins in both organization of 'physiological system and functions' and 'disease and disorder' were related significantly with 26 subcategories separately, while 24 subcategories were linked to 'molecular and cellular functions'. To understand the specific interaction of proteins that showed significant changes within functional groupings, we examined interaction networks generated by IPA (Fig. 6A). In 'molecular and cellular functions' classification, further downstream effect analysis within functional groupings of 'cellular growth and maintenance' revealed that the differentially expressed proteins were mainly associated with cellular homeostasis (Fig. 6B and C).

\section{Canonical signaling pathways of differentially expressed proteins}

IPA, a web-based tool, also highlighted two canonical signaling pathways, including the LXR/RXR activation pathway and the acute-phase response signaling pathway mediated by the greatest number of identified differentially expressed proteins along with a $z$-score representing the log probability being found by random chance. The differentially expressed proteins in endometrial cell lines were predominantly associated with the regulating pathways suggesting that they might have a critical role in embryo adhesion (Table 2).

\section{Upstream analysis}

Upstream regulator analysis may predict upstream molecules, including transcription factor, microRNA, kinase, compound or drug, which may cause the altered protein expression patterns. The results in Table 3 provided a list of upstream regulators related to embryo implantation that were predicted to be activated or inhibited based upon the activation $z$-score for uploaded differentially expressed protein profiles.

Published by Bioscientifica Ltd 
A

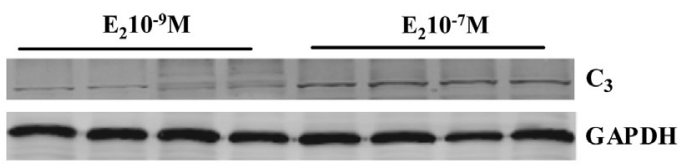

B

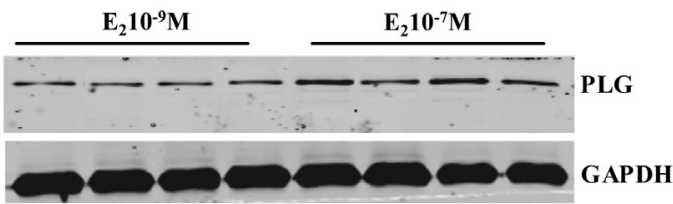

C

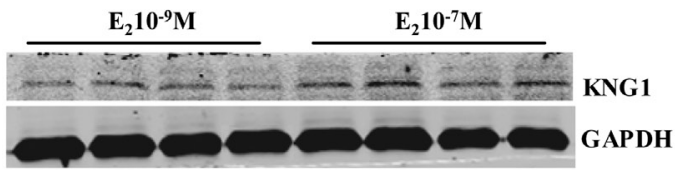

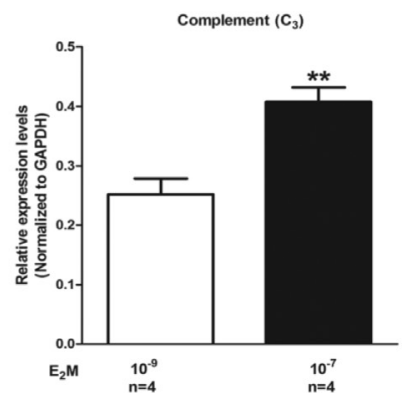
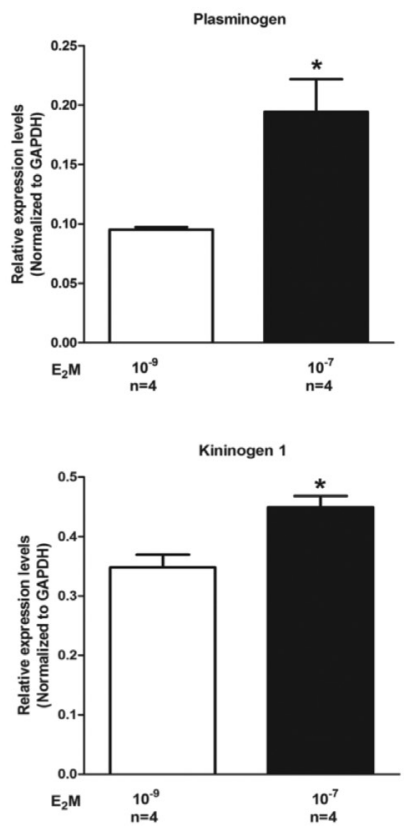

Figure 3

Differential expression of (A) $C_{3}$ (B) plasminogen and (C) kininogen-1 by Western blot. Data are present as mean \pm S.D. $(n=4) .{ }^{*}$ and $* *, P<0.05$ and $P<0.01$ compared with the corresponding control, respectively.

\section{Discussion}

Embryonic implantation in humans depends on the interaction of the embryo with the receptive endometrium. Exposure to high levels of $\mathrm{E}_{2}$ during $\mathrm{COH}$ in the early follicular phase is related to a lower chance of pregnancy and IVF outcome (Kolibianakis et al. 2003). Other investigators directed that supraphysiological $\mathrm{E}_{2}$ levels were not detrimental to IVF outcome (Levi et al. 2001, Peña et al. 2002). Kolb and Paulson (1997) reported that, in $\mathrm{COH}$, exposure to peak levels of $\mathrm{E}_{2}$ in the early luteal phase could lead to a time shift of the implantation window.

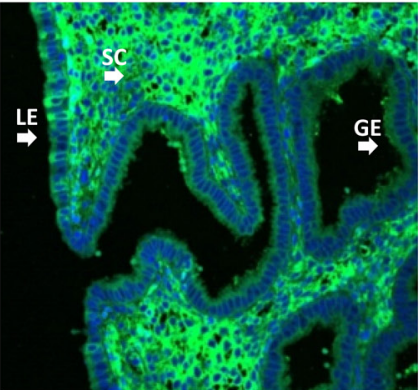

C3

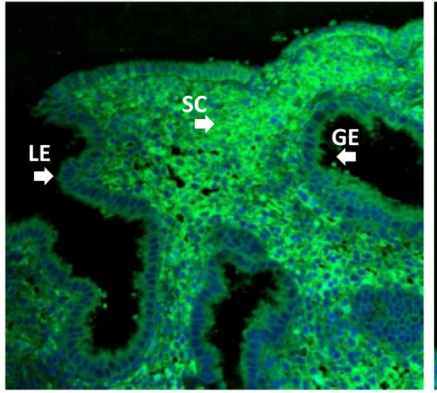

PLG

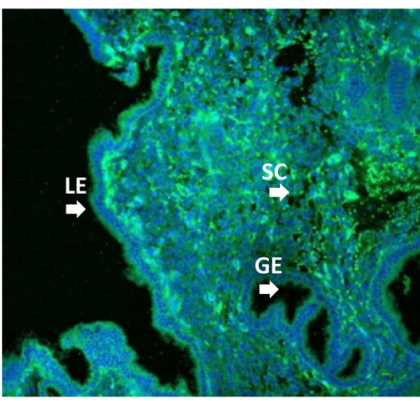

KNG1

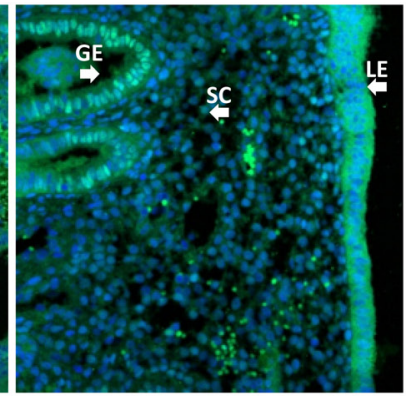

ERa

Figure 4

Localization of protein expression ( $C_{3}, \mathrm{KNG1}$, PLG and ER $\alpha$ ) in luminal epithelium (LE), glandular epithelium (GE) and stromal cells (SC) was examined in the human endometrium at the receptive phase by immunofluorescence $(\times 200)$. Green: $C_{3}$, KNG1, PLG and ER $\alpha$ staining. Blue: nuclei counterstained with DAPI.

$$
\begin{aligned}
& \text { http://jme.endocrinology-journals.org } \\
& \text { DOI: 10.1530/JME-17-0036 }
\end{aligned}
$$

() 2017 The authors Printed in Great Britain
Published by Bioscientifica Ltd 
A

\section{$A$ Molecular and
Cellular Functions}

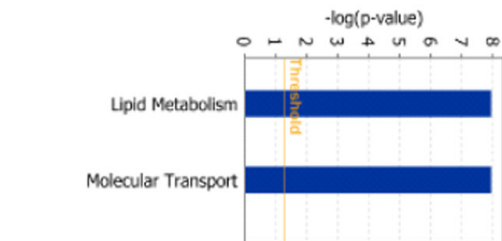

Small Molecule Biochemistry Cell-To-Cell Signaling and Interaction

Carbohydrate Metabolism

Cell Death and Surviva

Free Radical Scavenging

Cellular Movement

Cellular Growth and Proliferation

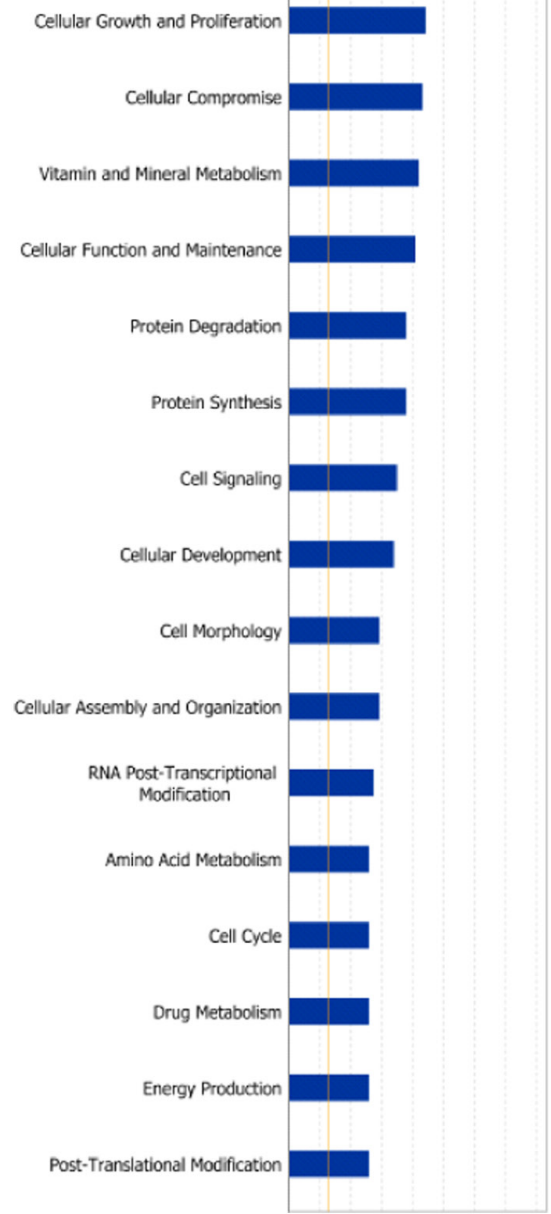

B

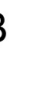

\section{Physiological System \\ and Functions}

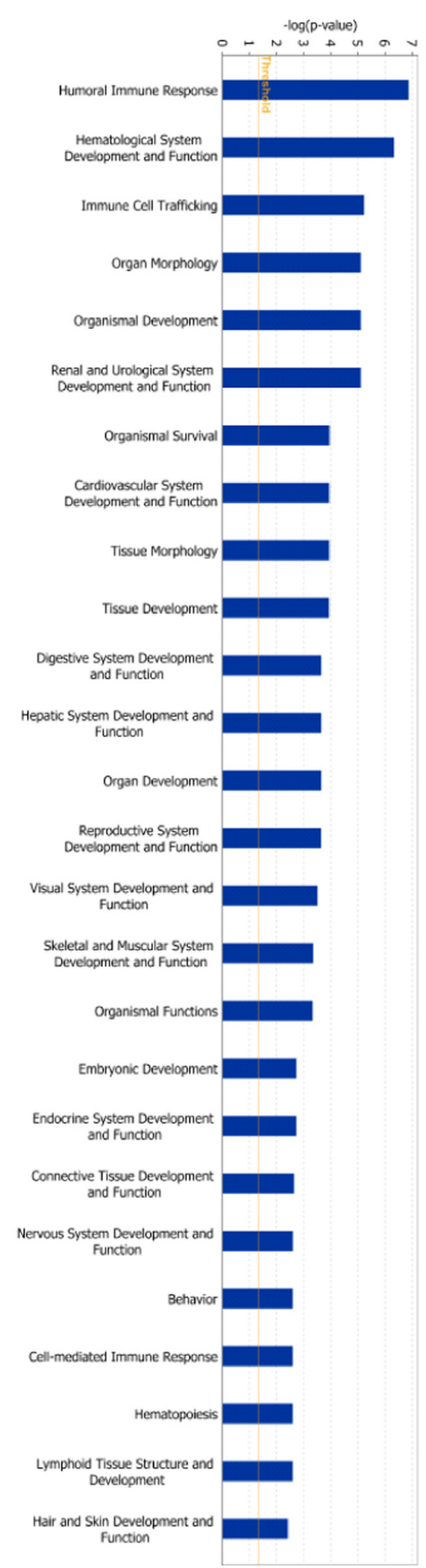

C

Disease and

Disorder

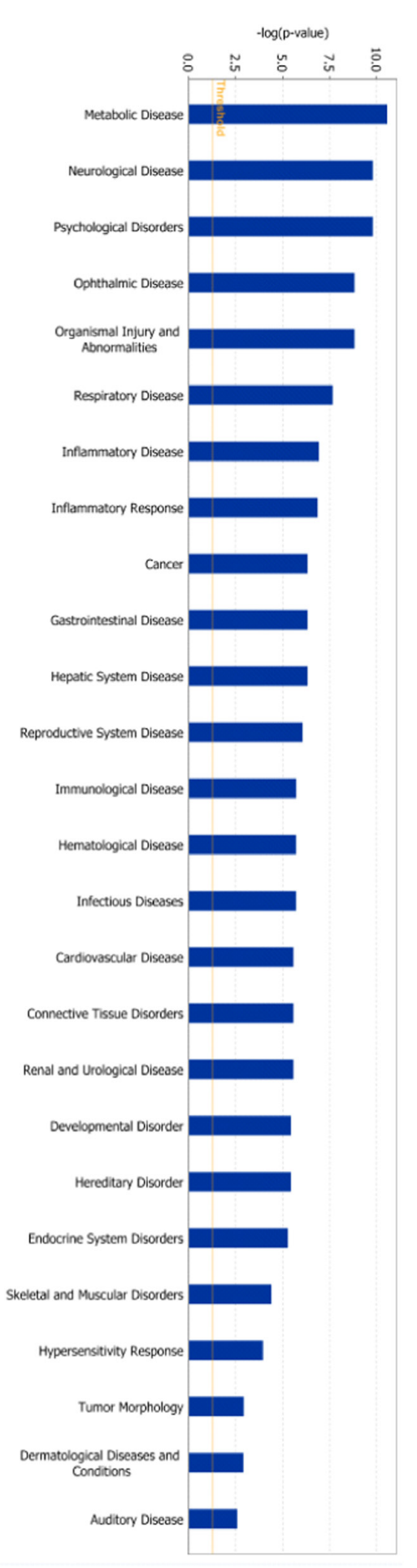

Figure 5

IPA-based functional analysis of 45 differentially expressed protein profiles. (A) Molecular and cellular functions; (B) physiological system and functions; (C) disease and disorder. A full colour version of this figure is available at http://dx.doi.org/10.1530/JME-17-0036.

\begin{tabular}{|lr} 
http://jme.endocrinology-journals.org & ○ 2017 The authors \\
DOI: 10.1530/JME-17-0036 & Printed in Great Britain
\end{tabular}

Published by Bioscientifica Ltd. 
A

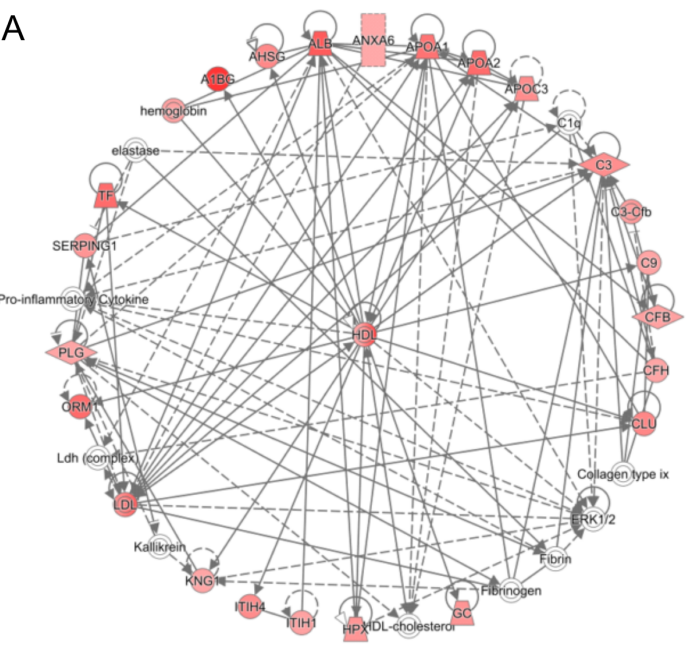

B

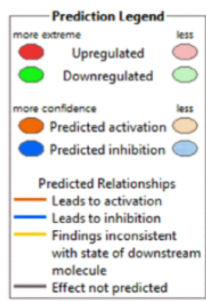

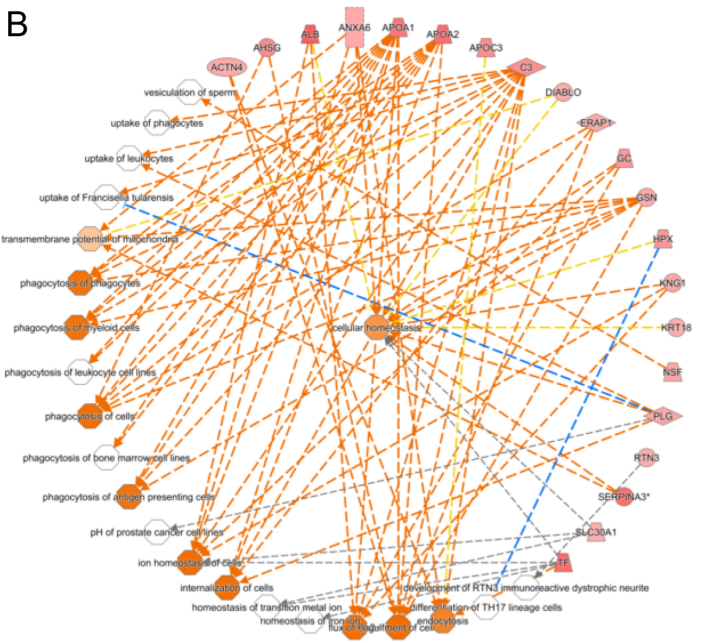

\begin{tabular}{|c|c|c|c|c|}
\hline $\begin{array}{l}\text { Diseases or Functions } \\
\text { Annotation }\end{array}$ & p-Value & $\begin{array}{l}\text { Activation } \\
\text { z-score }\end{array}$ & Molecules & $\begin{array}{l}\text { Molecules } \\
\text { numbers }\end{array}$ \\
\hline Cellular homeostasis & $6.65 \mathrm{E}-04$ & 1.091 & $\begin{array}{l}\text { ALB, ANXA6, APOA1, } \mathrm{C}_{3}, \text { DIABLO, GC, GSN, HPX, } \\
\text { KNG1, KRT18, PLG, SERPINA }{ }_{3}, \mathrm{SLC}_{3} \text { OA1, TF }\end{array}$ & 14 \\
\hline Ion homeostasis of cells & $8.38 \mathrm{E}-05$ & 2.413 & $\begin{array}{l}\text { ALB, ANXA }_{6}, \mathrm{APOA}_{1}, \mathrm{C}_{3}, \mathrm{GC}, \mathrm{HPX}, \mathrm{KNG1}, \mathrm{SLC} 30 \mathrm{~A} 1 \text {, } \\
\text { TF }\end{array}$ & 9 \\
\hline
\end{tabular}

\section{Figure 6}

(A) Top connectivity network among differentially expressed protein profiles. (B) Downstream effect analysis within functional group 'cellular function and maintenance'. The protein names and their temporal expression are shown in Table 1. Different color lines connecting proteins represent the relationships between them in Ishikawa cells (red coloration indicates an increase in expression, green indicates a decrease in expression and lack of color indicates a protein involved in bridging interactions, but was not identified as differentially regulated). The networks were generated through the use of IPA, genes or gene products are represented as nodes and the biological relationship between two nodes is represented as an edge. (C) Protein names and their temporal expression are listed in the table.

Joo and coworkers (2010) demonstrated that optimizing levels of serum $\mathrm{E}_{2}$ improved pregnancy outcome of in vitro fertilization in a concentration-dependent fashion during $\mathrm{COH}$ cycles. However, the enigma is still unclear. To clarify this issue and to examine the endometrial response to serum $\mathrm{E}_{2}$ levels, we designed the present study for the first time to compare and quantify the differentially expressed protein profiles in Ishikawa cells treated with different regimen of estrogen $\left(10^{-9} \mathrm{M}\right.$ and $\left.10^{-7} \mathrm{M}\right)$. We found that, compared to physiological concentration of $\mathrm{E}_{2} \quad\left(10^{-9} \mathrm{M}\right)$, supraphysiological $\mathrm{E}_{2}$ concentration $\left(10^{-7} \mathrm{M}\right)$ significantly increased the attachment rates of JAr spheroids to both human endometrial epithelial cell monolayers and Ishikawa cell monolayers. We evaluated that majority of proteins showed a significantly higher response to $10^{-7} \mathrm{M} \mathrm{E}_{2}$ compared to $10^{-9} \mathrm{M} \mathrm{E}_{2}$. Several proteins such as $\mathrm{C}_{3}$, SERPINs, plasminogen, kininogen-1, endoplasmic reticulum aminopeptidase-1 and alpha-1acid glycoprotein have been detected to be involved in endometrial receptivity. Previous efforts identified that $\mathrm{E}_{2}$ administration stimulated $\mathrm{C}_{3}$ synthesis in uterine luminal epithelial cells of rats (Sundstrom et al. 1989), whereas progesterone blocked induction of cell proliferation and $C_{3}$ synthesis in the epithelium of rat uterus (Bigsby 1993). In glandular epithelial cells of rat luteal endometrium $\mathrm{C}_{3}$ synthesis was upregulated by estrogen (Hasty et al. 1994). $C_{3}$ expression is also modulated by hCG in human endometrial compartments during the implantation

Table 2 IPA-defined canonical pathways for differentially expressed proteins identified by iTRAQ.

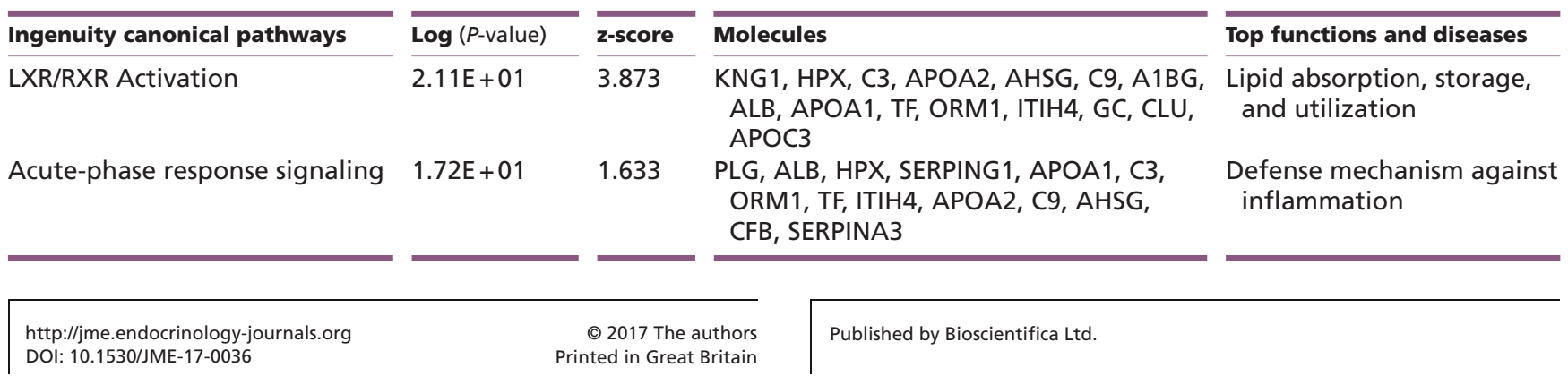


Table 3 IPA-based upstream analysis for $10^{-7} \mathrm{M} \mathrm{E}_{2}$ induced differentially expressed proteins associated with implantation.

\begin{tabular}{|c|c|c|c|c|}
\hline $\begin{array}{l}\text { Upstream } \\
\text { regulator }\end{array}$ & Molecule type & Predicted state & $\begin{array}{c}\text { Activation } \\
\text { z-score }\end{array}$ & $\begin{array}{c}P \text { value of } \\
\text { overlap }\end{array}$ \\
\hline TNF & Cytokine & Activated & 2.001 & $2.79 \mathrm{E}-02$ \\
\hline
\end{tabular}

IL6 Cytokine

Activated

2.36

Hmgn3 Other

Activated

2

$-2.236$

miR-140-3p

Mature-microRNA

Inhibited

3.73E-02 AASS, BCAS2,
ERAP, NSF,
WDR33

\begin{tabular}{l} 
Target molecules \\
in dataset \\
\hline ALB, APOA1, C3, \\
CFB, CLU, ORM1, \\
SERPINA3, TF
\end{tabular}

Finding(s)

n uterus of female TNFo

cyclic expression causes proliferation of numerous types of cells (Kopf et al. 1994, Tabibzadeh et al. 1995)

4.06E-06

ALB, APOA1, C3, CLU, HPX KRT-18, ORM1, PLG, SERPINA3, TF

8.04E-07 AHSG, APOA1, APOA2, KNG1 WDR33
Cyclic expression of IL-1, IL-6 mediate cells proliferation in female uterus. IL-6 deficient (-/-) mice showed reduced implantation sites, impaired immune and acute-phase responses (Kopf et al. 1994,

Tabibzadeh et al. 1995)

Hmgn3 modulate Hand2 gene expression in uterine cells (Okada et al. 2014). Hand-2 deficient (-/-) gene led to implantation failure in mice (Okada et al. 2014) miR-140-3p affect expression of putative targets in endometrial stromal cells in vitro (Okada et al. 2014) window (Palomino et al. 2013). We detected high levels of $\mathrm{C}_{3}$ in Ishikawa cells after $10^{-7} \mathrm{M} \mathrm{E}_{2}$ treatment, suggesting a significantly endometrial response to a reasonable serum $\mathrm{E}_{2}$ level in controlled ovarian stimulation. The data from the present study also demonstrated significant expression of $\mathrm{C}_{3}$ in the receptive-phase endometrium. Plasminogen activators (PA) in human endometrium play an important role in pathophysiological aspects of tissue expansion and remodeling. Ovarian hormonal patterns affect cyclic expression of the activity of plasminogen activators, predominantly t-PA. Estrogen stimulates PA synthesis while progesterone declines their synthesis (Koh et al. 1992). In normal endometrium, cyclic variation and distribution of UPA, UPAR and plasminogen activator inhibitor 1 (PAI-1) have been reported with discordant levels of uPA in both proliferative and secretory phases, while UPAR only in the secretory phase (Nordengren et al. 2004). In our present findings, plasminogen and a number of potent SERPINs that modulate the proteolytic activities of PA (tPA/uPA) (Lee et al. 2011) have been determined to be significantly upregulated in the endometrial cells during $10^{-7} \mathrm{M} \mathrm{E}_{2}$ treatment. Kallikreinkinin system has a key role in many inflammatory processes during proliferation of the endometrial lining of uterus (Clements et al. 1997). The present findings revealed high expression levels of kininogen-1 in human endometrial epithelial cells after $10^{-7} \mathrm{M} \mathrm{E}_{2}$ treatment, indicating that kallikrein-kinin system may be activated. Interestingly, the distribution and localization of PLG and KNG1 in the human endometrial compartments at the receptive phase of the cycle reflects their involvement in endometrial preparations for implantations. The presence and distribution of several aminopeptidases including A-LAP and ERAP1 have been shown to be related with cell proliferation and differentiation of human endometrium (Shibata et al. 2004). In our results, significant changes in expression level of ERAP1 were detected in Ishikawa cells treated with $10^{-7} \mathrm{M} \mathrm{E}_{2}$. Future studies will be directed to delineate the hormone-induced physiological changes in kallikrein-kinin system and aminopeptidases in various phases of the endometrium. Additionally, a key event in the eukaryotic gene regulation is the post-translational acetylation of nucleosomal histones upon decidualization (Sakai et al. 2003). Consistent with the most recent data (Piras et al. 2017), we detected increased expression levels of histones $\left(\mathrm{H}_{1}-\mathrm{H}_{4}\right)$ in cells treated with $10^{-7} \mathrm{M} \mathrm{E}_{2}$. In women undergoing IVF treatment, metabolomic analysis of follicular fluid revealed a decrease in levels of choline, glycerophosphocholine and phosphocholine in patients whose fertilized oocyte failed to cleave to an embryo (Wallace et al. 2012). In contrast, $10^{-7} \mathrm{M} \mathrm{E}_{2}$ treatment significantly downregulated expression level of choline in

Published by Bioscientifica Ltd. 
human endometrial epithelial cells in vitro. IPA program is applied to determine predicted upstream regulators, signaling pathways or group of proteins identified by iTRAQ. In the present study, IPA generated top connectivity network of 45 differentially expressed proteins. Proteins including highlighted $\mathrm{C}_{3}$, SERPINs, PLG, KNG1 and number of other proteins in the confirmed network might change the metabolic status of the endometrium toward a receptive stage. Downstream functional enrichment analysis of cellular function and maintenance showed that most proteins in this network were upregulated in the human endometrial epithelial cells treated with $10^{-7} \mathrm{M} \mathrm{E}_{2}$, and these upregulated proteins were related to cellular homeostasis. After analyzing the association of the differentially expressed proteins with cellular functions and maintenance, we found that 14 proteins could be categorized as being involved in cellular homeostasis and 9 proteins could be categorized as being involved in ion homeostasis of cells. Differentially expressed proteins detected in present study also mediated signaling pathways such as the LXR/RXR activation pathway and the acute-phase response signaling pathway involved in lipid metabolism and inflammation (Mouzat et al. 2009, Birse et al. 2013) respectively. In mouse endometrium and myometrium, two isoforms of liver $\mathrm{X}$ receptors (LXRa and LXRb) are expressed, suggesting the existence of a molecular link between cholesterol levels, LXRs and deregulation of ovulation, particularly in ovarian hyperstimulation syndrome (OHSS) (Mouzat et al. 2009). In vivo study showed that Lxr-deficient (-/-) mice offered some signs of infertility (Steffensen et al. 2006). RXR was found to be constitutively expressed throughout the gestation (Plösch et al. 2010). Furthermore, clinical studies are needed to explain their role in OHSS patients. Our upstream analysis listed several upstream regulators identified in Ishikawa cells treated with $10^{-7} \mathrm{M} \mathrm{E}_{2}$. However, extensive investigations are required to elucidate their biological significance by validating target genes relevant to implantation and pregnancy.

\section{Conclusions}

In summary, the systematic analyses provide the basis for understanding the estrogen-dependent changes in protein profiles of endometrial compartments with some distinct proteins relevant to uterine receptivity and suggest that optimized dosage fashion of estrogen regimen may maintain high pregnancy rates and probable target endometrium at the endometrial-embryonic interface in high responders. Moreover, to determine sufficient management and to validate minimal ovarian hyperstimulation along with late embryo transfer, further molecular and clinical researches are needed to clarify the underlying mechanisms of different effects of estrogen at different doses on embryo implantation in $\mathrm{COH}$ patients.

\section{Declaration of interest}

The authors declare that there is no conflict of interest that could be perceived as prejudicing the impartiality of the research reported.

\section{Funding}

This study was supported by the National Basic Research Program of China (No. 2012 CB944900 to H F H), the Natural Science Foundation of China (81450038, 31171444 to H F H; 81300458 to T T W and 81270708 to J Z S), NSFC-CIHR Joint Health Research Programs (81361128007 to J Z S) and a Canadian Institutes for Health Research China-Canada Joint Health Research Initiative grant (CCl-132570 to P C K L).

\section{Authors' contribution statement}

$\mathrm{K} \mathrm{U}, \mathrm{H} \mathrm{F} \mathrm{H}$ and $\mathrm{J} Z \mathrm{~S}$ designed the experiment. $\mathrm{K} \mathrm{U}, \mathrm{T} U \mathrm{R}, \mathrm{H} T \mathrm{P}, \mathrm{X} Y \mathrm{D}$, $L Y J, J L$ and $Y C$ performed the experiments. $K U, M X G, Z H K, J R, X H L$, $\mathrm{X} X \mathrm{Q}$ and $\mathrm{T} T \mathrm{~T}$ acquired and analyzed the data. $\mathrm{K} \mathrm{U}, \mathrm{T} U \mathrm{R}, \mathrm{H} \mathrm{FH}$ and J Z S wrote the manuscript.

\section{Acknowledgments}

This study was supported by the National Basic Research Program of China (No. 2012CB944900 to H F H), the Natural Science Foundation of China (81450038, 31171444 to H F H, 81300458 to T T W and 81270708 to J Z S), NSFC-CIHR Joint Health Research Programs (81361128007 to J Z S) and a Canadian Institutes for Health Research China-Canada Joint Health Research Initiative grant (CCl-132570 to P C K L).

\section{References}

Bigsby RM 1993 Progesterone and dexamethasone inhibition of estrogen-induced synthesis of DNA and complement in rat uterine epithelium: effects of antiprogesterone compounds. Journal of Steroid Biochemistry and Molecular Biology 45 295-301. (doi:10.1016/09600760(93)90345-W)

Birse KM, Burgener A, Westmacott GR, McCorrister S, Novak RM \& Bal TB 2013 Unbiased proteomics analysis demonstrates significant variability in mucosal immune factor expression depending on the site and method of collection. PLOS ONE 8 e79505. (doi:10.1371/ journal.pone.0079505)

Castelbaum AJ, Ying L, Somkuti SG, Sun J, Ilesanmi AO \& Lessey BA 1997 Characterization of integrin expression in a well differentiated endometrial adenocarcinoma cell line (Ishikawa) 1. Journal of Clinical Endocrinology and Metabolism 82 136-142. (doi:10.1210/jc.82.1.136)

Chenette PE, Sauer MV \& Paulson RJ 1990 Very high serum estradiol levels are not detrimental to clinical outcome of in vitro fertilization. Fertility and Sterility 54 858-863. (doi:10.1016/S0015-0282(16)53946-6)

Clements J, Mukhtar A, Yan S \& Holland A 1997 Kallikreins and kinins in inflammatory-like events in the reproductive tract. Pharmacological Research 35 537-540. (doi:10.1006/phrs.1997.0183) http://jme.endocrinology-journals.org

DOI: 10.1530/JME-17-0036
(C) 2017 The authors Printed in Great Britain
Published by Bioscientifica Ltd 
Cox J \& Mann M 2008 MaxQuant enables high peptide identification rates, individualized ppb-range mass accuracies and proteome-wide protein quantification. Nature Biotechnology 26 1367-1372. (doi:10.1038/nbt.1511)

Cox J, Matic I, Hilger M, Nagaraj N, Selbach M, Olsen JV \& Mann M 2009 A practical guide to the MaxQuant computational platform for SILAC-based quantitative proteomics. Nature Protocols 4 698-705. (doi:10.1038/nprot.2009.36)

Cox J, Neuhauser N, Michalski A, Scheltema RA, Olsen JV \& Mann M 2011 Andromeda: a peptide search engine integrated into the MaxQuant environment. Journal of Proteome Research 10 1794-1805. (doi:10.1021/pr101065j)

Dominguez F, Garrido-Gomez T, Lopez J, Camafeita E, Quinonero A Pellicer A \& Simon C 2009 Proteomic analysis of the human receptive versus non-receptive endometrium using differential in-gel electrophoresis and MALDI-MS unveils stathmin 1 and annexin A2 as differentially regulated. Human Reproduction 24 2607-2617. (doi:10.1093/humrep/dep230)

Fossum GT, Davidson A \& Paulson RJ 1989 Ovarian hyperstimulation inhibits embryo implantation in the mouse. Journal of in Vitro Fertilization and Embryo Transfer 6 7-10. (doi:10.1007/BF01134574)

Hannan NJ, Paiva P, Dimitriadis E \& Salamonsen LA 2010 Models for study of human embryo implantation: choice of cell lines? Biology of Reproduction 82 235-245. (doi:10.1095/biolreprod.109.077800)

Hasty LA, Lambris JD, Lessey BA, Pruksananonda K \& Lyttle CR 1994 Hormonal regulation of complement components and receptors throughout the menstrual cycle. American Journal of Obstetrics and Gynecology 170 168-175. (doi:10.1016/S0002-9378(13)70300-4)

Heneweer C, Schmidt M, Denker H-W \& Thie M 2005 Molecular mechanisms in uterine epithelium during trophoblast binding: the role of small GTPase RhoA in human uterine Ishikawa cells. Journal of Experimental and Clinical Assisted Reproduction 24. (doi:10.1186/1743-1050-2-4)

Hohn HP, Linke M \& Denker HW 2000 Adhesion of trophoblast to uterine epithelium as related to the state of trophoblast differentiation: in vitro studies using cell lines. Molecular Reproduction and Development 57 135-145. (doi:10.1002/10982795(200010)57:2<135::AID-MRD4>3.0.CO;2-9)

Joo BS, Park SH, An BM, Kim KS, Moon SE \& Moon HS 2010 Serum estradiol levels during controlled ovarian hyperstimulation influence the pregnancy outcome of in vitro fertilization in a concentrationdependent manner. Fertility and Sterility 93 442-446. (doi:10.1016/j. fertnstert.2009.02.066)

Koh S, Wong P, Yuen R, Chua S, Ng B \& Ratnam S 1992 Concentration of plasminogen activators and inhibitor in the human endometrium at different phases of the menstrual cycle. Journal of Reproduction and Fertility 96 407-413. (doi:10.1530/jrf.0.0960407)

Kolb BA, Najmabadi S \& Paulson RJ 1997 Ultrastructural characteristics of the luteal phase endometrium in patients undergoing controlled ovarian hyperstimulation. Fertility and Sterility 67 625-630. (doi:10.1016/S0015-0282(97)81356-8)

Kolb BA \& Paulson RJ 1997 The luteal phase of cycles utilizing controlled ovarian hyperstimulation and the possible impact of this hyperstimulation on embryo implantation. American Journal of Obstetrics and Gynecology 176 1262-1269. (doi:10.1016/S00029378(97)70344-2)

Kolibianakis EM, Albano C, Kahn J, Camus M, Tournaye H, Van Steirteghem AC \& Devroey P 2003 Exposure to high levels of luteinizing hormone and estradiol in the early follicular phase of gonadotropin-releasing hormone antagonist cycles is associated with a reduced chance of pregnancy. Fertility and Sterility 79 873-880. (doi:10.1016/S0015-0282(02)04920-8)

Kopf M, Baumann H, Freer G, Freudenberg M, Lamers M, Kishimoto T, Zinkernagel R, Bluethmann H \& Köhler G 1994 Impaired immune and acute-phase responses in interleukin-6-deficient mice. Nature 368 339-342. (doi:10.1038/368339a0)
Lee RK-K, Fan C-C, Hwu Y-M, Lu C-H, Lin M-H, Chen Y-J \& Li S-H 2011 SERPINE2, an inhibitor of plasminogen activators, is highly expressed in the human endometrium during the secretory phase. Reproductive Biology and Endocrinology 9 1. (doi:10.1186/ 1477-7827-9-1)

Levi AJ, Drews MR, Bergh PA, Miller BT \& Scott RT 2001 Controlled ovarian hyperstimulation does not adversely affect endometrial receptivity in in vitro fertilization cycles. Fertility and Sterility $\mathbf{7 6}$ 670-674. (doi:10.1016/S0015-0282(01)01988-4)

Mirkin S, Nikas G, Hsiu J-G, Díaz J \& Oehninger S 2004 Gene expression profiles and structural/functional features of the peri-implantation endometrium in natural and gonadotropin-stimulated cycles. Journal of Clinical Endocrinology and Metabolism 89 5742-5752. (doi:10.1210/ jc.2004-0605)

Mo B, Vendrov AE, Palomino WA, DuPont BR, Apparao K \& Lessey BA 2006 ECC-1 cells: a well-differentiated steroid-responsive endometrial cell line with characteristics of luminal epithelium. Biology of Reproduction 75 387-394. (doi:10.1095/biolreprod.106.051870)

Mouzat K, Volat F, Baron S, Alves G, Pommier AJ, Volle DH, Marceau G, DeHaze A, Déchelotte P \& Duggavathi R 2009 Absence of nuclear receptors for oxysterols liver $\mathrm{X}$ receptor induces ovarian hyperstimulation syndrome in mice. Endocrinology $1503369-3375$. (doi:10.1210/en.2008-1519)

Ng EHY, Yeung WSB, Lau EYL, So WWK \& Ho PC 2000 High serum oestradiol concentrations in fresh IVF cycles do not impair implantation and pregnancy rates in subsequent frozen-thawed embryo transfer cycles. Human Reproduction 15 250-255. (doi:10.1093/humrep/15.2.250)

Nordengren J, Pilka R, Noskova V, Ehinger A, Domanski H, Andersson C, Høyer-Hansen G, Hansson S \& Casslén B 2004 Differential localization and expression of urokinase plasminogen activator (uPA), its receptor (UPAR), and its inhibitor (PAI-1) mRNA and protein in endometrial tissue during the menstrual cycle. Molecular Human Reproduction 10 655-663. (doi:10.1093/molehr/gah081)

Okada H, Tsuzuki T, Shindoh H, Nishigaki A, Yasuda K \& Kanzaki H 2014 Regulation of decidualization and angiogenesis in the human endometrium: mini review. Journal of Obstetrics and Gynaecology Research 40 1180-1187. (doi:10.1111/jog.12392)

Palomino WA, Argandoña F, Azúa R, Kohen P \& Devoto L 2013 Complement C3 and decay-accelerating factor expression levels are modulated by human chorionic gonadotropin in endometrial compartments during the implantation window. Reproductive Sciences 20 1103-1110 (doi:10.1177/1933719113477486)

Papageorgiou T, Guibert J, Goffinet F, Patrat C, Fulla Y, Janssens Y \& Zorn J-R 2002 Percentile curves of serum estradiol levels during controlled ovarian stimulation in 905 cycles stimulated with recombinant FSH show that high estradiol is not detrimental to IVF outcome. Human Reproduction 17 2846-2850. (doi:10.1093/ humrep/17.11.2846)

Paulson RJ, Sauer MV \& Lobo RA 1990 Embryo implantation after human in vitro fertilization: importance of endometrial receptivity. Fertility and Sterility 53 870-874. (doi:10.1016/S00150282(16)53524-9)

Peña JE, Chang PL, Chan L-K, Zeitoun K, Thornton MH \& Sauer MV 2002 Supraphysiological estradiol levels do not affect oocyte and embryo quality in oocyte donation cycles. Human Reproduction $\mathbf{1 7}$ 83-87. (doi:10.1093/humrep/17.1.83)

Piras C, Guo Y, Soggiu A, Chanrot M, Greco V, Urbani A, Charpigny G, Bonizzi L, Roncada P \& Humblot P 2017 Changes in protein expression profiles in bovine endometrial epithelial cells exposed to E. coli LPS challenge. Molecular BioSystems 13 392-405. (doi:10.1039/ c6mb00723f)

Plösch T, Gellhaus A, van Straten E, Wolf N, Huijkman N, Schmidt M, Dunk C, Kuipers F \& Winterhager E 2010 The liver X receptor (LXR) and its target gene ABCA1 are regulated upon low oxygen in human trophoblast cells: a reason for alterations in 
preeclampsia? Placenta 31 910-918. (doi:10.1016/j.

placenta.2010.07.009)

Sakai N, Maruyama T, Sakurai R, Masuda H, Yamamoto Y, Shimizu A, Kishi I, Asada H, Yamagoe S \& Yoshimura Y 2003 Involvement of histone acetylation in ovarian steroid-induced decidualization of human endometrial stromal cells. Journal of Biological Chemistry $\mathbf{2 7 8}$ 16675-16682. (doi:10.1074/jbc.M211715200)

Sharara FI \& McClamrock HD 1999 Ratio of oestradiol concentration on the day of human chorionic gonadotrophin administration to midluteal oestradiol concentration is predictive of in-vitro fertilization outcome. Human Reproduction 14 2777-2782. (doi:10.1093/ humrep/14.11.2777)

Sheng Q, Dai J, Wu Y, Tang H \& Zeng R 2012 BuildSummary: using a group-based approach to improve the sensitivity of peptide/protein identification in shotgun proteomics. Journal of Proteome Research 11 1494-1502. (doi:10.1021/pr200194p)

Shibata D, Ando H, Iwase A, Nagasaka T, Hattori A, Tsujimoto M \& Mizutani S 2004 Distribution of adipocyte-derived leucine aminopeptidase (A-LAP)/ER-aminopeptidase (ERAP)-1 in human uterine endometrium. Journal of Histochemistry and Cytochemistry 52 1169-1175. (doi:10.1369/jhc.3A6216.2004)

Simón C, Mercader A, Frances A, Gimeno MJ, Polan ML, Remohí J \& Pellicer A 1996 Hormonal regulation of serum and endometrial IL- $1 \alpha$, IL-1 $\beta$ and IL-1ra: IL-1 endometrial microenvironment of the human embryo at the apposition phase under physiological and supraphysiological steroid level conditions. Journal of Reproductive Immunology 31 165-184. (doi:10.1016/0165-0378(96)00982-5)

Simón C, Velasco JJG, Valbuena D, Peinado JA, Moreno C, Remohí J \& Pellicer A 1998 Increasing uterine receptivity by decreasing estradiol levels during the preimplantation period in high responders with the use of a follicle-stimulating hormone step-down regimen. Fertility and Sterility 70 234-239. (doi:10.1016/s0015-0282(98)00140-x)
Steffensen KR, Robertson K, Gustafsson J-Å \& Andersen CY 2006 Reduced fertility and inability of oocytes to resume meiosis in mice deficient of the Lxr genes. Molecular and Cellular Endocrinology 256 9-16. (doi:10.1016/j.mce.2006.03.044)

Sundstrom SA, Komm B, Ponce-de-Leon H, Yi Z, Teuscher C \& Lyttle C 1989 Estrogen regulation of tissue-specific expression of complement C3. Journal of Biological Chemistry 264 16941-16947.

Tabibzadeh S, Kong Q, Babaknia A \& May L 1995 Progressive rise in the expression of interleukin-6 in human endometrium during menstrual cycle is initiated during the implantation window. Human Reproduction 10 2793-2799. (doi:10.1093/oxfordjournals.humrep. a135793)

Valbuena D, Jasper M, Remohí J, Pellicer A \& Simón C 1999 Ovarian stimulation and endometrial receptivity. Human Reproduction $\mathbf{1 4}$ 107-111. (doi:10.1093/humrep/14.suppl_2.107)

Valbuena D, Martin J, de Pablo JL, Remohí J, Pellicer A \& Simón C 2001 Increasing levels of estradiol are deleterious to embryonic implantation because they directly affect the embryo. Fertility and Sterility 76 962-968. (doi:10.1016/S0015-0282(01)02018-0)

Wallace M, Cottell E, Gibney MJ, McAuliffe FM, Wingfield M \& Brennan L 2012 An investigation into the relationship between the metabolic profile of follicular fluid, oocyte developmental potential, and implantation outcome. Fertility and Sterility 97 1078.e1078-1084. e1078. (doi:10.1016/j.fertnstert.2012.01.122)

Wisniewski JR, Zougman A, Nagaraj N \& Mann M 2009 Universal sample preparation method for proteome analysis. Nature Methods 6 359. (doi:10.1038/nmeth.1322)

Zhang Y, Chen Q, Zhang H, Wang Q, Li R, Jin Y, Wang H, Ma T, Qiao J \& Duan E 2015 Aquaporin-dependent excessive intrauterine fluid accumulation is a major contributor in hyper-estrogen induced aberrant embryo implantation. Cell Research 25 139. (doi:10.1038/ cr.2014.139)

Received in final form 21 May 2017

Accepted 24 May 2017

Accepted Preprint published online 24 May 2017 http://jme.endocrinology-journals.org

DOI: 10.1530/JME-17-0036
() 2017 The authors Printed in Great Britain
Published by Bioscientifica Ltd 